\title{
Expanding catchment-scale hydrologic restoration in suburban watersheds via stream mitigation crediting-A Northern Kentucky (USA) case study
}

\author{
Robert J. Hawley ${ }^{1}$ (D) \\ Accepted: 14 June 2021 / Published online: 28 June 2021 \\ (c) The Author(s) 2021
}

\begin{abstract}
The need for hydrologic restoration is well established in stream ecosystems across the world; however, available funding for catchment-scale restoration typically falls far short of what is required to produce in-stream results. Hydrologic restoration can be particularly important for improving stream integrity in urban watersheds, but implementation can be challenging due to high property values and limited space for retroactive stormwater control measures. This Northern Kentucky (USA) case study summarizes how stormwater mitigation interventions could be, and have already been, used to credit stream mitigation projects via conventional US Army Corps of Engineers crediting protocols. Hydrologic restoration can generate stream mitigation credits by directly improving the flow class and/or by indirectly improving the habitat quality. For example, a stormwater intervention could create a shift from an ephemeral to intermittent flow class, while at the same time facilitating greater substrate stability, lower embeddedness, and other geomorphic improvements, that subsequently improve the categorical habitat rating. The ecological lift of such hydrologic interventions could be further expanded via concurrent in-stream mitigation measures such as re-establishing a jurisdictional stream in place of a drainage ditch or installing habitat structures such as toe wood and log steps, among other activities. Such process-based hydrologic restoration is consistent with the goals of the Clean Water Act and has the potential to be more beneficial to greater portions of stream networks and greater numbers of stakeholders than conventional habitat restoration alone.
\end{abstract}

Keywords Stream restoration $\cdot$ Stormwater management $\cdot$ Hydrologic restoration $\cdot$ Stream mitigation $\cdot$ Suburban watersheds $\cdot$ Watershed restoration

\section{Introduction}

This study documents how stormwater interventions that restore a more natural flow and disturbance regime can facilitate improvements in stream integrity that align with stream mitigation program goals and can be credited using conventional US protocols. By generating stream mitigation credits, hydrologic restoration programs could receive sustainable sources of funding at scales necessary to drive watershed-scale improvements in stream networks. Hydrologic-driven impacts (i.e. "hydromodification") are a leading cause of impairments to US water resources (EPA 2009). Inadequately managed

Robert J. Hawley

bob.hawley@sustainablestreams.com

1 Sustainable Streams, LLC, 1948 Deer Park Avenue, Louisville, KY 40205, USA stormwater runoff from impervious surfaces is a primary cause of the "urban stream syndrome" (Walsh et al. 2005a, b) — a global phenomenon of degraded biological, chemical, and physical stream integrity in streams draining urban and suburban watersheds (Fig. 1). A sweeping study by the National Research Council of the National Academies documented that these impacts typically persist in suburban watersheds even with conventional stormwater control measures (SCMs) such as detention basins designed for peak discharge matching (NRC 2009).

Both the conventionally-managed and unmanaged flow regime can increase the frequency (Hawley et al. 2017) and durations (Bledsoe 2002; Hawley and Bledsoe 2011) of flows that exceed the critical discharge $\left(\mathrm{Q}_{\text {critical }}\right.$, or $\left.\mathrm{Q}_{\mathrm{c}}\right)$ for mobilization of the streambed material (Fig. 2). For example, one Northern Kentucky study conducted by the United States Environmental Protection Agency / Office of Research and Development (EPA/ORD) and collaborators 


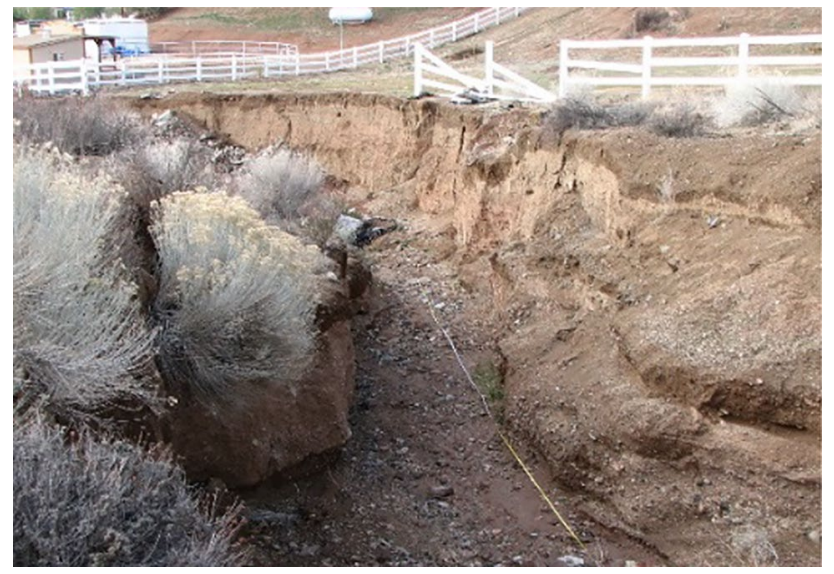

Fig. 1 Channel degradation in S. CA coinciding with a shift from $\sim 2$ to $10 \%$ watershed imperviousness-see Hawley and Bledsoe (2013)

found that conventional peak detention reduced the recovery time between disturbance events by $\sim$ four-fold (e.g. from the 12-month to 3-month design storm). The study also found that durations of discharges that exceed $\mathrm{Q}_{\text {critical }}$ were prolonged by a factor of 25 (e.g. $~ 34.8 \mathrm{~h}$ over a $20-\mathrm{yr}$ period compared to $\sim 1.4 \mathrm{~h}$ under pre-development conditions, Hawley et al. 2017). Similar geomorphically-relevant hydrologic responses to conventional suburban/urbanization have been documented across the globe (Russell et al. 2018; e.g. Papangelakis et al. 2019). In aggregate, more frequent, prolonged durations of erosive flows increase the cumulative energy expressed on the streambed and banks, which can initiate degradation via channel incision (Booth 1990), enlargement (Hammer 1972; Hawley and Bledsoe 2013), bed coarsening (Hawley et al. 2013; Pizzuto et al. 2000),

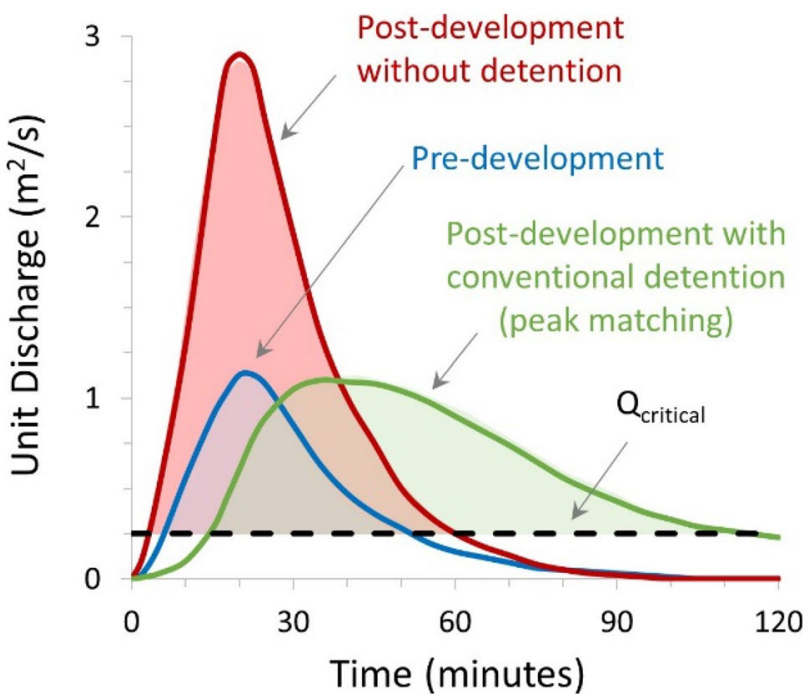

Fig. 2 Conventional "peak matching" detention can prolong durations that exceed $\mathrm{Q}_{\text {critical }}$ and mobilize streambed particles (2-yr, 2-h event for Ft. Collins, CO, adapted from Bledsoe (2002)) habitat simplification (e.g. fewer benches) (Vietz et al. 2014) and less large wood (Finkenbine et al. 2000; Blauch and Jefferson 2019) among other impacts. Chronic channel instability and bank erosion can be a dominant source of fine sediment loads (Simon and Klimetz 2008) that can further impact benthic habitat through sedimentation and embeddedness, and is a leading water quality impairment in numerous states (OEPA 2010; e.g. KDOW 2008).

The degradational trajectory of streams experiencing increasingly erosive bed-mobilizing flows has been observed by numerous researchers across a diversity of urban settings (Paul and Meyer 2001; Hawley et al. 2012, 2020; Booth and Fischenich 2015), and is typically consistent with the "classic" Channel Evolution Model (CEM) of Schumm et al. (1984) (Fig. 3). Incision and downcutting (Stage 2) lead to taller, more unstable banks, which subsequently causes bank failure and channel widening (Stage 3). As the banks continue to slump and lose material to the stream, the channel begins to aggrade sediment, typically in the form of large, unstable bars (Stage 4). Over a long enough period of widening and aggradation, the slumped material can be recolonized by vegetation (i.e. "vegetated benches"), creating a new channel/floodplain corridor that is once again in a state of geomorphic equilibrium (Stage 5).

However, this natural adjustment process can be disrupted through additional perturbations (Cluer and Thorne 2014) such as supplemental changes to the flow regime (e.g. further watershed development) and localized channel stabilization efforts that can be particularly common in urban areas (Vietz and Hawley 2019). Furthermore, property and infrastructure protection efforts can facilitate alternative channel endpoints such as an artificially armored channel via continuous riprap or concrete (Hawley et al. 2012).

Excess streambed disturbance can also adversely impact the aquatic ecosystem. For example, flows that exceed $\mathrm{Q}_{\text {critical }}$ can cause both non-lethal dislodgement and direct mortality to benthic macroinvertebrates that inhabit the streambed (Holomuzki and Biggs 2000). In a seven-year study at a reference site with otherwise excellent habitat and water quality, the interannual shifts in biotic integrity were largely explained by streambed disturbance (Hawley et al. 2016). Kentucky's Macroinvertebrate Index for Biotic Integrity (MBI) was significantly correlated to the number of days since an event that exceeded $\mathrm{Q}_{\text {critical }}$ (Fig. 4), with more consecutive days of streambed stability leading to higher MBI scores. The influence of bed-mobilizing "disturbance events" on macroinvertebrate communities is so widely acknowledged by aquatic biologists and ecologists that many conventional sampling protocols preclude data collection for two weeks following such events (e.g. KDOW 2015).

In streams draining suburban and urban watersheds, the effects of amplified rates of streambed disturbance (i.e. the "urban disturbance regime," Hawley and Vietz 2016) 


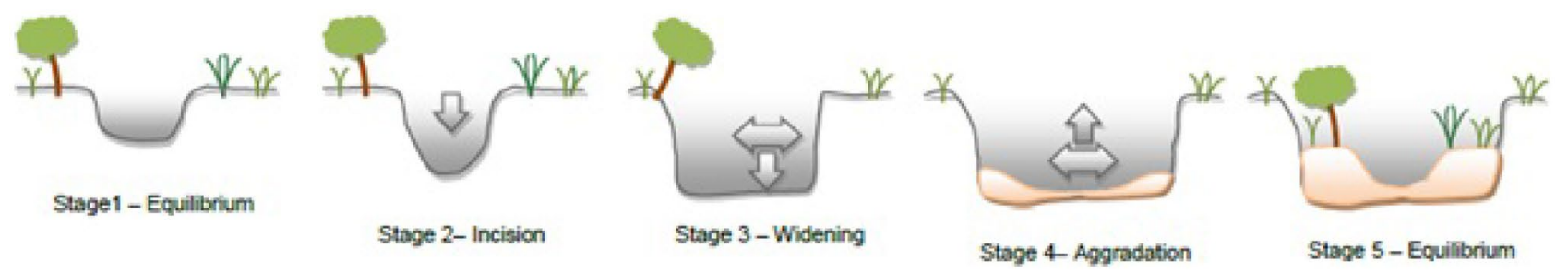

Fig. 3 Channel Evolution Sequence in response to increased flows from urbanization ( adapted from Schumm et al. (1984) and Hawley et al. (2012))

is discernible across the full gradient of urbanization. For example, after accounting for a watershed's total impervious area (TIA), Hawley et al. (2016) showed that MBI at a given level of TIA drops by an average of 20-30 points during exceptionally wet years with frequent $Q_{\text {critical }}$ events (e.g. 2011) as compared to sample years with much greater bed stability (e.g. reference sites had more than 300 days of stability in 2009) (Fig. 5). Years that show the steepest drop in MBI along a gradient of TIA (e.g. 2007 and 2008, Fig. 5) correspond to years where a storm produced flows that approached (but did not exceed) $\mathrm{Q}_{\text {critical }}$ at reference sites, but likely coincided with enough stormwater runoff in developed watersheds to cause a bed-mobilizing event at developed sites. That is, MBI remained high at sites draining undeveloped watersheds where flows did not exceed $\mathrm{Q}_{\text {critical }}$, but MBI was exceptionally poor at developed sites where flows likely exceeded $\mathrm{Q}_{\text {critical }}$ (due to inadequate stormwater management).

One of the central aims of a hydrologic approach to stream restoration is to restore a more natural disturbance

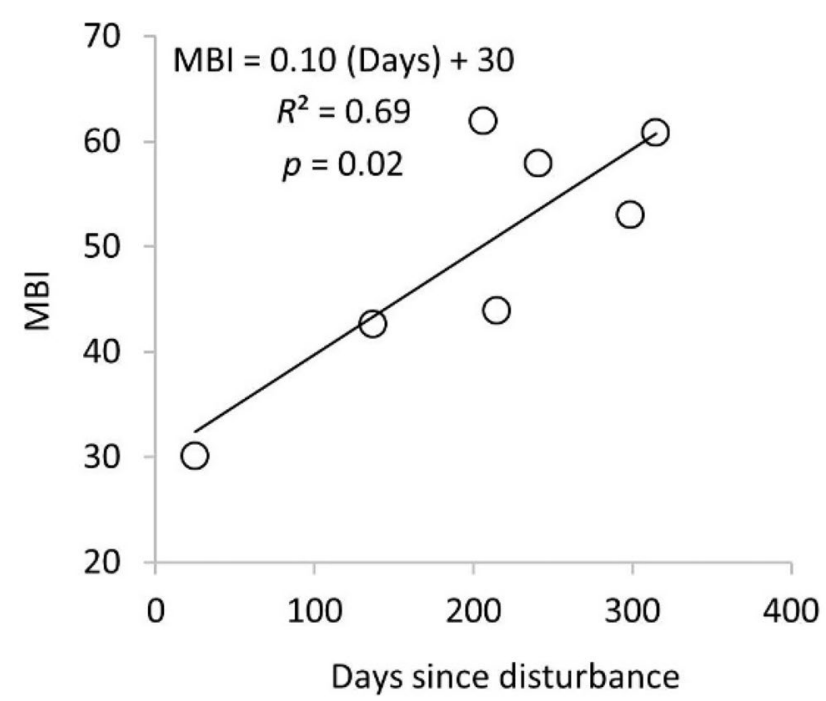

Fig. 4 Kentucky's Macroinvertebrate Index for Biotic Integrity (MBI) at a Northern Kentucky reference site is significantly correlated to the number of days since a bed-mobilizing event ( adapted from Hawley et al. 2016) regime by intercepting and attenuating stormwater runoff, thereby reducing the frequency and duration of events that exceed $\mathrm{Q}_{\text {critical }}$. By focusing on the primary driver of channel degradation, watershed-scale stormwater interventions can not only mitigate excess disturbance but also have the greatest mechanistic potential to induce water quality improvements (Walsh et al. 2005a, b). In a review of 100 studies on SCM effectiveness at the watershed scale, Jefferson et al. (2017) concluded that water quality effectiveness coincided with SCMs that created the largest runoff reductions. That is, volume-based SCMs not only have the greatest potential to restore a more natural flow and disturbance regime, but also show the most promise for improving water quality due (Jefferson et al. 2017).

Finally, hydrologic-based restoration has the potential to extend benefits to greater portions of the stream network and potentially greater numbers of stakeholders than can typically be achieved with conventional in-stream habitat restoration (Hawley 2018). Lammers et al. (2019) showed that stormwater mitigation approaches tend to have a greater potential to improve water quality than conventional stream restoration approaches, but even larger reductions in sediment and nutrient loads can be achieved through projects that couple both flow and in-stream restoration. And, just as inadequately managed stormwater runoff creates visually discernible changes in baseflows (Bhaskar et al. 2016) and responses to rain events (Fig. 6), flow restoration has the potential to positively impact both downstream stakeholders and aquatic communities in very tangible ways such as reduced flashiness, restored baseflows, and improved channel stability.

Restoring a more natural flow and disturbance regime is therefore one of the most pressing needs to meeting the goals of the Clean Water Act (Booth 2005; Harman et al. 2012). Beyond inadequate stakeholder engagement (e.g. Herrington and Horndeski In review; Bixler et al. In review, Kaushal et al. Forthcoming this issue), one of the biggest barriers to watershed-scale flow restoration is cost. For example, a King County (2013) study that proposed distributed green infrastructure to restore a more natural flow regime was estimated to cost over $\$ 7 \mathrm{M}$ per $\mathrm{km}^{2}$ of controlled drainage area. Even lower cost alternatives such as 
Fig. 5 MBI in northern Kentucky streams significantly decreases with watershed imperviousness, particularly when segregated by sample year, underscoring the role of exceptionally frequent benthic disturbance in wet years such as 2011 as compared to years with less frequent $\mathrm{Q}_{\text {critical }}$ exceedance such as 2009 ( adapted from Hawley et al. 2016)

$\begin{array}{lcc}\begin{array}{l}\text { Disturbance } \\ \text { Frequency/ } \\ \text { Severity }\end{array} & \begin{array}{c}\text { Monitoring } \\ \text { Years }\end{array} & \begin{array}{c}\text { Days since a Q Qritical } \\ \text { event at Reference } \\ \text { Site MDC 5.5 }\end{array} \\ \text { Lowest } & 2009 / 2014 & 215-315 \\ \text { Low } & 2010 / 2013 & 241-299 \\ \text { Intermediate } & 2007 / 2008 & 206^{\text {(a) }} \\ \text { High } & 2011 & 25\end{array}$

Qualitative Range in MBI at:

$\begin{array}{cc}\text { Reference Sites } & \text { 20-30\% TIA } \\ \text { Good-Excellent } & \text { Fair-Excellent } \\ \text { Good - Excellent } & \text { Poor - Good } \\ \text { Poor - Excellent } & \text { Very Poor - Poor } \\ \text { Poor - Good } & \text { Very Poor - Poor }\end{array}$

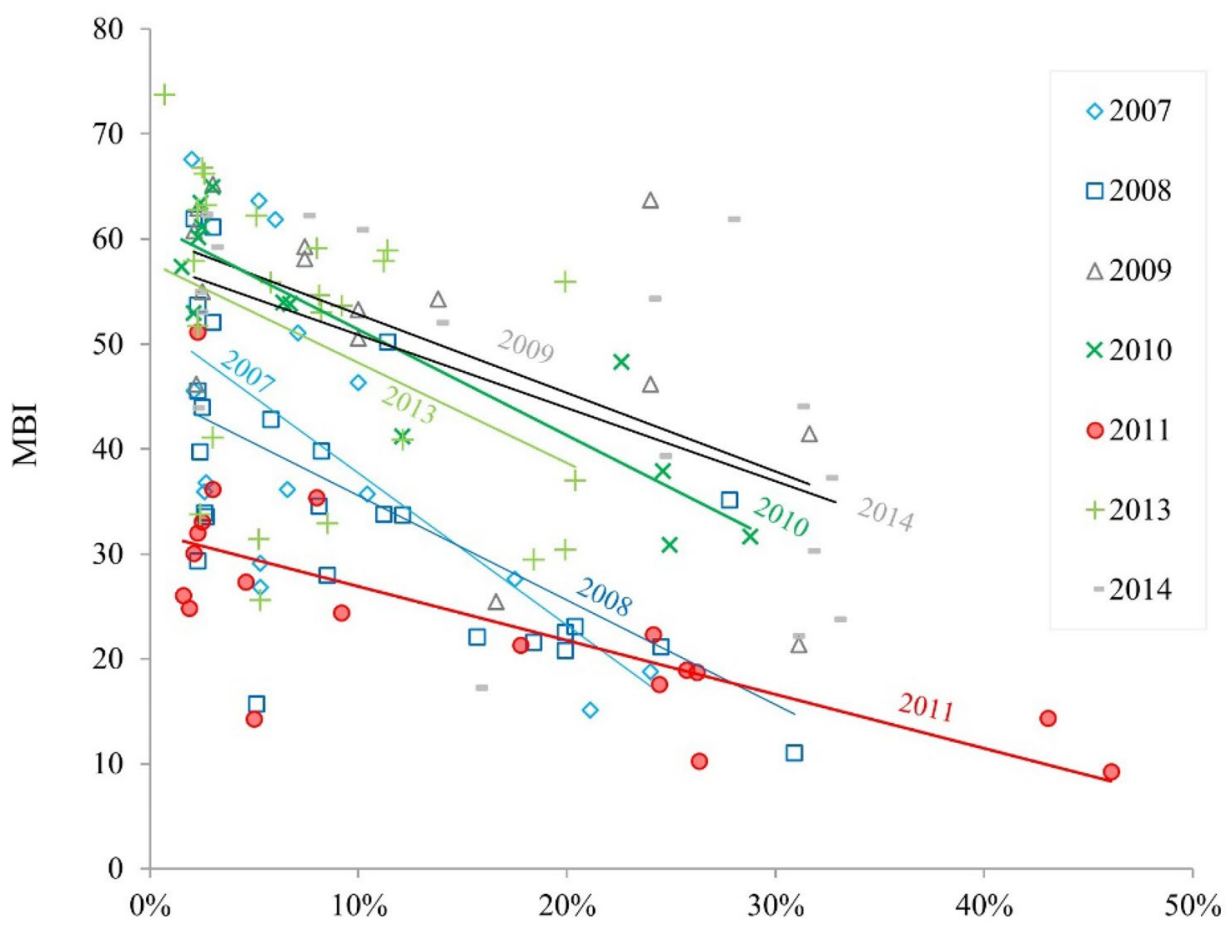

Total Impervious Area

retrofits of existing detention basins are estimated at more than $\$ 100 \mathrm{k}$ per $\mathrm{km}^{2}$ of controlled drainage area (Hawley et al. 2017).

Compensatory stream mitigation programs in the US, such as those administered by the Army Corps of Engineers (USACE) under the authority of the Clean Water Act, aim to restore comparable levels of aquatic habitat that were impacted by practices such as filling or culverting to accommodate other societal needs such as urban expansion, road/utility development, and reservoirs. 'Credits' associated with stream mitigation (and corresponding fees associated with impacts) typically have values on the order of several hundred US dollars (e.g. \$400 in Kentucky https://fw.ky.gov/Fish/Pages/StreamTeam-Program.aspx). Although crediting protocols can vary by USACE District and ecoregion, stream mitigation activities can typically generate $\sim 0.05$ to 3 credits per foot of stream (e.g. $\$ 65$ to $\$ 4,000$ per meter in Kentucky) depending on habitat quality, flow class and mitigation treatment.

Stream mitigation programs have predominately focused on the physical restoration of aquatic habitat, but crediting protocols are increasingly considering watershed-scale hydrologic factors and other components of stream integrity (TDEC 2018; Harman et al. 2012). This case study documents how stormwater interventions that restore a more natural flow and disturbance regime can produce stream restoration outcomes that align with programmatic mitigation goals. Such hydrologic restoration projects could not only generate credits with protocols that explicitly account for hydrologic factors (e.g. TDEC 2018) but also with conventional USACE protocols that only incorporate habitat quality and flow class. By providing a better understanding of stream mitigation credit values for watershed-scale 

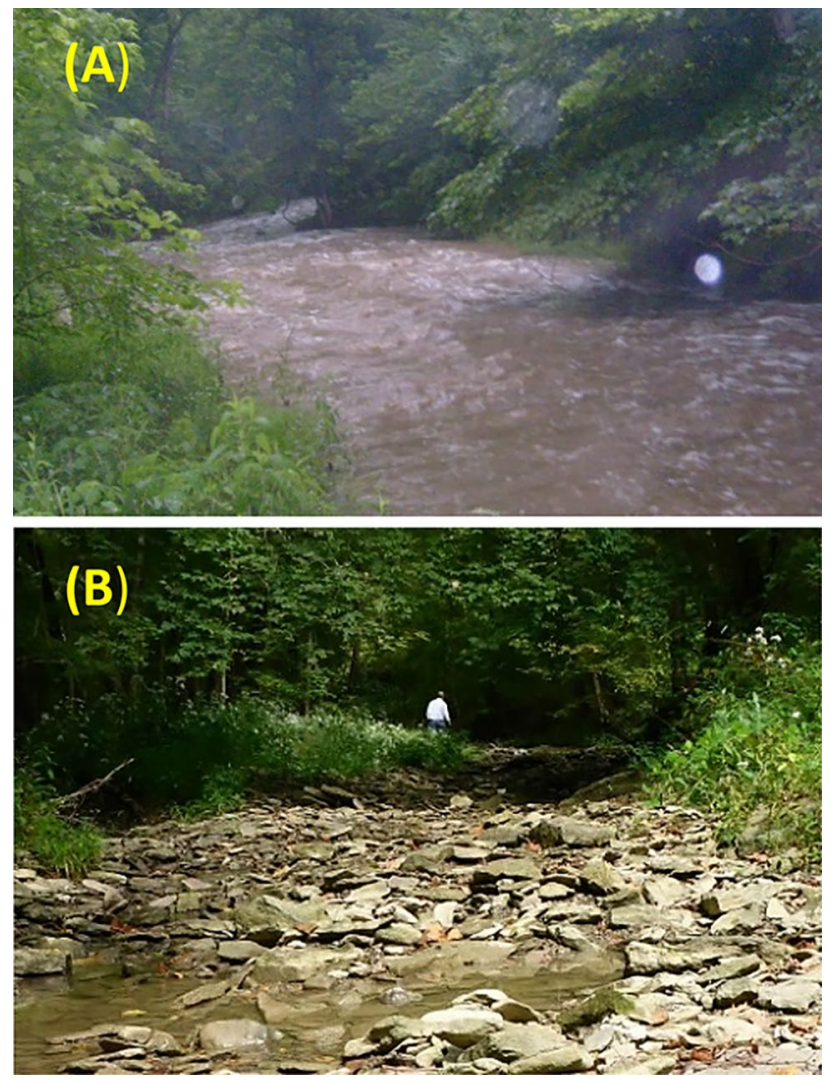

Fig. $67.5 \mathrm{~mm}$ of rain in $1 \mathrm{~h}$ creates visually apparent differences in the hydrologic and hydraulic responses of two Northern Kentucky streams: a $5.7 \mathrm{~km}^{2}$ watershed with $29 \%$ TIA (A) and an undeveloped $4.7 \mathrm{~km}^{2}$ watershed with $3 \%$ TIA (B)

stormwater interventions using conventional habitat/flow class protocols, this case study could be a step toward expanded economic and regulatory incentives (and/or reduced barriers) for more holistic stream mitigation programs that restore urban streams and meet other societal objectives such as delivering services to historically underrepresented communities (Smith et al. 2016).

\section{Stream mitigation crediting in kentucky}

Stream crediting protocols exist because not all streams provide comparable levels of habitat quality or ecosystem functions. For example, a high quality perennial stream can typically support fish communities with its permanently wet pools, whereas streams with only seasonal flow permanence might be more important for amphibian reproduction (Meyer et al. 2007). USACE (2009) stream mitigation credits in much of Kentucky are based on the Central Kentucky Assessment Protocol (https://fw.ky.gov/Fish/Pages/Stream-Team-Program.aspx). Adjusted Mitigation Units (AMUs) are based on a combination of flow type (i.e. ephemeral, intermittent, or perennial) and habitat quality (i.e. Rapid Bioassessment Protocol (RBP) classes
Table 1 Kentucky's AMU quality values ${ }^{\mathrm{a}}$ are based on a combination of flow class and habitat (RBP) quality

\begin{tabular}{lllll}
\hline Flow Type & & Ephemeral & Intermittent & Perennial \\
\hline Habitat Quality & Poor & 0.5 & 1.0 & 1.5 \\
(RBP) & Average & 0.75 & 1.5 & 2.25 \\
& Excellent & 1.0 & 2.0 & 3.0 \\
\hline
\end{tabular}

${ }^{\mathrm{a}}$ If completely vegetated channel bottom, enter 0

of poor, average, or excellent, (KDOW 2011) Table 1). RBP habitat quality has long been used as a surrogate for biological community integrity (Plafkin et al. 1989; Barbour et al. 1999), and individual components of RBP such as low amounts of fine sediment, low embeddedness, and coarse/stable substrate continue to be highly correlated to the abundance and density of sensitive taxa such as Ephemeroptera, Plecoptera, and Trichoptera compared to purely geometric indices such as stream slope and the width to depth ratio (e.g. Kowalski and Richer 2020).

The AMU value for an existing stream can be calculated by determining the Initial Quality value for a representative reach (Table 1) and multiplying it by its respective length in US customary units of feet (Eq. 1). For example, 1,000 feet $(305 \mathrm{~m})$ of a poor-quality perennial stream would correspond to a Quality value of 1.5 and be worth a total of 1,500 AMUs $(1,000 \mathrm{ft} \times 1.5) .{ }^{1}$ AMU credits for Mitigation Treatments typically use both the Initial and Final Quality values (Table 1), scaled by the Mitigation Ratio (Table 2) according to Eq. 2. For example, enhancement (Mitigation Ratio of 0.5 ) of 1,000 feet $(305 \mathrm{~m}$ ) of a poor-quality perennial stream (Initial Quality of 1.5) that is restored to an excellent-quality perennial stream (Final Quality of 3.0) would correspond to a net increase of 750 AMUs or "Mitigation Credits" (1,000 $\mathrm{ft} \times 0.5 \times(3.0-1.5))$.

AMU Value for an Existing Stream, including the Debit Value for a Re-establishment Reach

$A M U=$ Length $\times$ InitialQuality

where: $A M U=$ Adjusted Mitigation Units

Length $=$ stream length in feet

Initial Quality = Initial Quality value based on flow and habitat (Table 1).

AMU Credits for Mitigation Treatments

$A M U=$ Length $\times$ MitigationRatio $\times($ FinalQuality - InitialQuality $)$

where: $A M U=$ Adjusted Mitigation Units

\footnotetext{
${ }^{1}$ All credit calculation examples included herein assume the associated stream length is protected by a conservation easement (or equivalent) that includes the conventional buffer width $(50 \mathrm{ft}, 15 \mathrm{~m})$ on both sides of the stream (Table 2).
} 
Table 2 Mitigation ratios ${ }^{\mathrm{b}}$ are based on restoration treatment

\begin{tabular}{ll}
\hline Mitigation Type & $\begin{array}{l}\text { Mitigation } \\
\text { Ratio }^{\mathrm{b}}\end{array}$ \\
\hline Re-establishment & 1.0 \\
Rehabilitation & 1.0 \\
Enhancement & 0.5 \\
Preservation & 0.1 \\
No Action & 0.0 \\
\hline
\end{tabular}

${ }^{\mathrm{b}}$ Mitigation Ratio may decrease without the full buffer width (50 $\mathrm{ft}, 15 \mathrm{~m}$ ) and may increase with a wider buffer.

Length $=$ stream length in feet

Mitigation Ratio $=$ Mitigation Ratio for Restoration Treatment (Table 2)

Final Quality $=$ Final Quality value based on flow and habitat (Table 1)

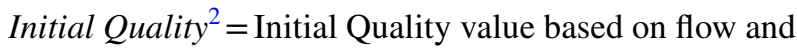
habitat (Table 1)

It is important to note that Mitigation Credits for preservation reaches are not deducted for their Initial Quality because it is typically the same as the Final Quality. As such, the Initial Quality is effectively dropped from Eq. 2 for preservation reaches (i.e. Preservation AMUs $=$ Length $\times 0.1 \times$ Quality).

Another special case involves channel re-establishment, where a stream is re-meandered into a more geomorphically appropriate alignment. Channel re-establishment often coincides with filling the former channel, and the AMU value of the filled channel is calculated via Eq. 1 so that it can be "debited" against the mitigation credits of the restored stream (Eq. 2) where the "Initial Quality" is valued as 0 . The so-called "debit/credit" approach is necessary to account for potential differences in stream length between the pre-project and restored reaches.

\section{How could hydrologic restoration improve stream credit values?}

The existing USACE (2009) stream mitigation crediting protocol for central Kentucky could be used to facilitate mitigation credits for hydrologic restoration activities along two primary pathways: by directly improving the flow type and/ or indirectly improving the habitat quality (RBP). For example, hydrologic restoration could potentially change a stream

\footnotetext{
${ }^{2}$ For re-establishment reaches where AMUs are both "credited" (Eq. 2) and "debited" (Eq. 1), the Initial Quality in Eq. 2 is valued as 0. "Debits" and "Credits" are used to account for potential differences in stream length between post-project (e.g. re-meandered) and pre-project (e.g. channelized) conditions. For preservation reaches, there is no deduction for the Initial Quality (i.e. Preservation AMUs $=$ Length $\times 0.1 \times$ Quality)
}

from ephemeral to intermittent, from intermittent to perennial, or even from ephemeral to perennial. In the EPA/ORD pilot study mentioned above, Hawley et al. (2017) showed how a simple restriction of a conventional detention basin outlet at a Toyota parts facility (i.e. the "Toyota" project) reduced flow flashiness (Fig. 7), restored a more natural disturbance regime, and prolonged baseflows. By extending ponding durations (Fig. 8) and inducing more topsoil saturation within the detention basin, gage data showed that the passive retrofit device, co-patented between US EPA and Sustainable Streams (Hawley et al. 2019), converted an intermittent stream with pools that used to go dry 10\% of the time to a stream with several pools that are nearly permanently wet (Hawley et al. 2017) where fish have been observed during seasonal low-flow visits on September 16, 2016 and July 8, 2019.

\section{Categorical lifts in habitat quality}

An indirect, but potentially just as effective, avenue to create stream restoration credits via hydrologic restoration is by facilitating a recovery in stream habitat. Regardless of whether the EPA/ORD pilot project created a change in flow class, the less erosive flow regime has resulted in discernable improvements in habitat quality. Moreover, by addressing the dominant driver of channel instability in the suburban stream network, the process-based approach has promoted a shift from a degradational trajectory toward a gradual return of geomorphic equilibrium (CEM Stage 5, Fig. 3) via bench development, bank re-stabilization, and increased wood retention, among other geomorphic processes.

To track the hydrologic, geomorphic, and habitat responses of the detention basin retrofit project, Hawley et al. (2017) established three monitoring sites in the receiving stream network (see Supplemental Material for location maps). The "Spur" is the $\sim 800-\mathrm{ft}(\sim 245-\mathrm{m})$ reach that is the direct tributary of the retrofit detention basin. The drainage area to the Spur is $0.17 \mathrm{~km}^{2}$ with $45 \%$ TIA according to 2016 NLCD data. The upstream monitoring site ("US site") is a control site that receives no drainage from the detention basin. Its drainage area is $1.10 \mathrm{~km}^{2}$ with $7.8 \%$ TIA. The downstream monitoring site ("DS site") is on the secondorder stream that is downstream of the confluence of the Spur and US site reaches. The drainage area to the DS site is $1.31 \mathrm{~km}^{2}$ with $12.4 \%$ TIA. Nearly half $(47 \%)$ of the TIA that drains to the DS site comes from the Spur site (e.g. the Toyota parts facility that is managed by the retrofit detention basin) even though the Spur only contributes $\sim 13 \%$ of the total drainage area to the DS site.

Since the detention retrofit installation on December 21, 2013, geomorphic data compiled by Hawley et al. (2020) documented a shift in the streambed material at the Spur site 
(A) Pre-retrofit 10/31/13

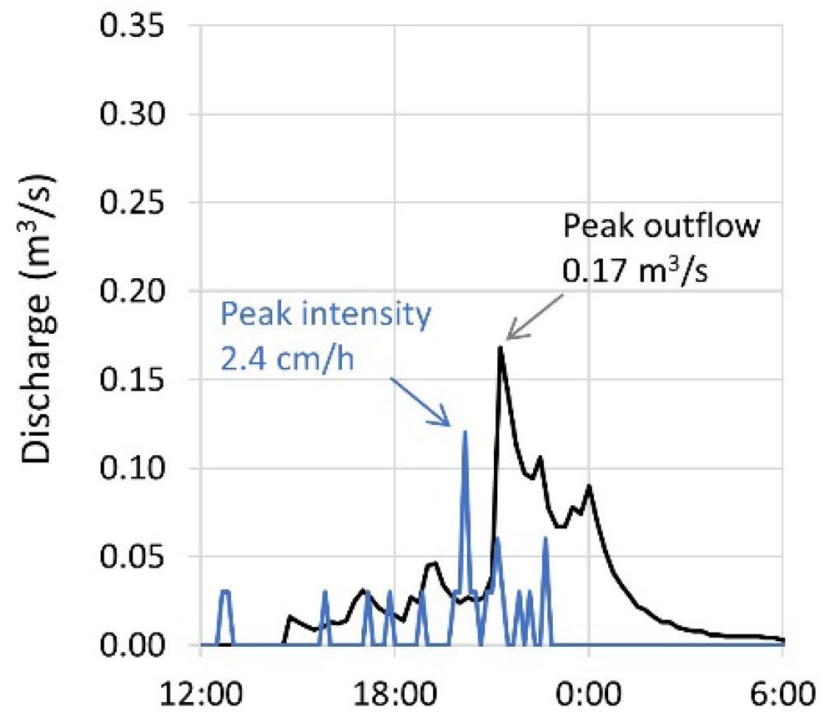

(B) Post-retrofit 6/4/14

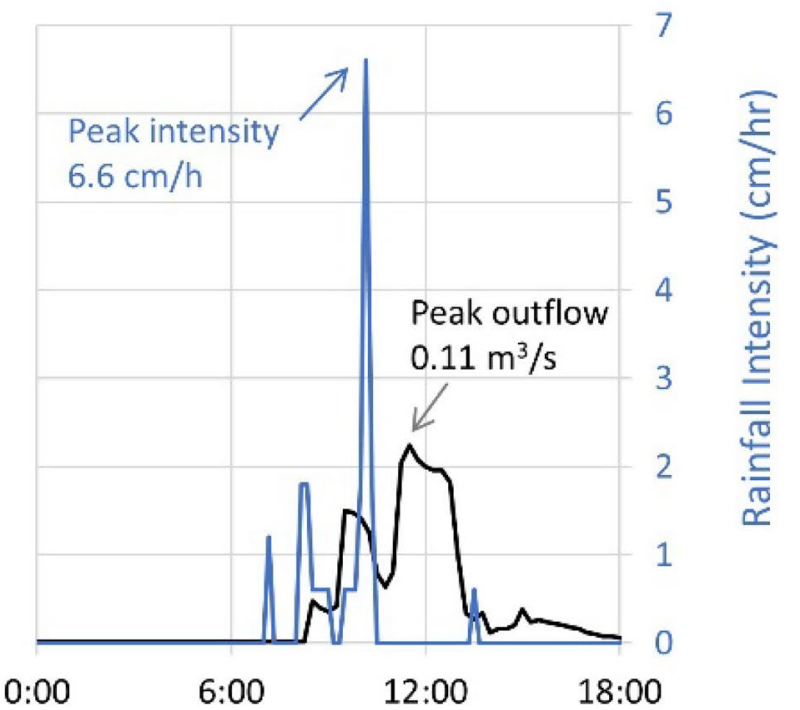

Fig. 7 Precipitation and discharge hydrographs for pre-retrofit (A) and post-retrofit (B) events of a conventional detention basin piloted by EPA/ ORD and collaborators document the reduced flashiness and restricted discharges with the SCM retrofit ( adapted from Hawley et al. 2017)

from a degradational (CEM Stage 3) to an aggregational/ recovery trajectory (CEM Stages 4/5, Fig. 3). The shift is also apparent in the photos from pre-retrofit and post-retrofit installation (Fig. 9), which show bench development at the toes of formerly unstable banks. Combined with greater flow permanence and much higher wood retention throughout the reach, this has not only improved bank and bed stability but increased habitat complexity as the channel has begun to reestablish a meandering low-flow channel. The RBP score has improved from 113 in 2013 to 143 in 2019 (see Supplemental Material), corresponding to a shift from poor to average habitat quality (KDOW 2011). As an intermittent stream with a length of $\sim 800$ feet $(\sim 245 \mathrm{~m})$, this would generate 200 AMUs if credited as enhancement $(800 \mathrm{ft} \times 0.5 \times(1.5-1.0))$ and 400 AMUs if credited as rehabilitation $(800 \mathrm{ft} \times 1.0 \times(1.5-1.0))$.

By contrast, the US control site that had no stormwater interventions experienced a degradational trajectory over the same time period. Vegetated benches were scoured
Fig. 8 Detention basin retrofit devices such as the Detain $\mathrm{H} 2 \mathrm{O}$ (co-patented between US EPA and Sustainable Streams, Hawley et al. 2019) can be optimized to restrict most events to discharges that no longer cause downstream erosion via a restricted primary outlet (A). Additional photos document the device in advance of $(\mathbf{B})$ and during $(\mathbf{C})$ the $6 / 4 / 14$ event from Fig. 7, underscoring the attenuated discharges and prolonged ponding induced by the restricted outlet ( adapted from Hawley et al. 2017)
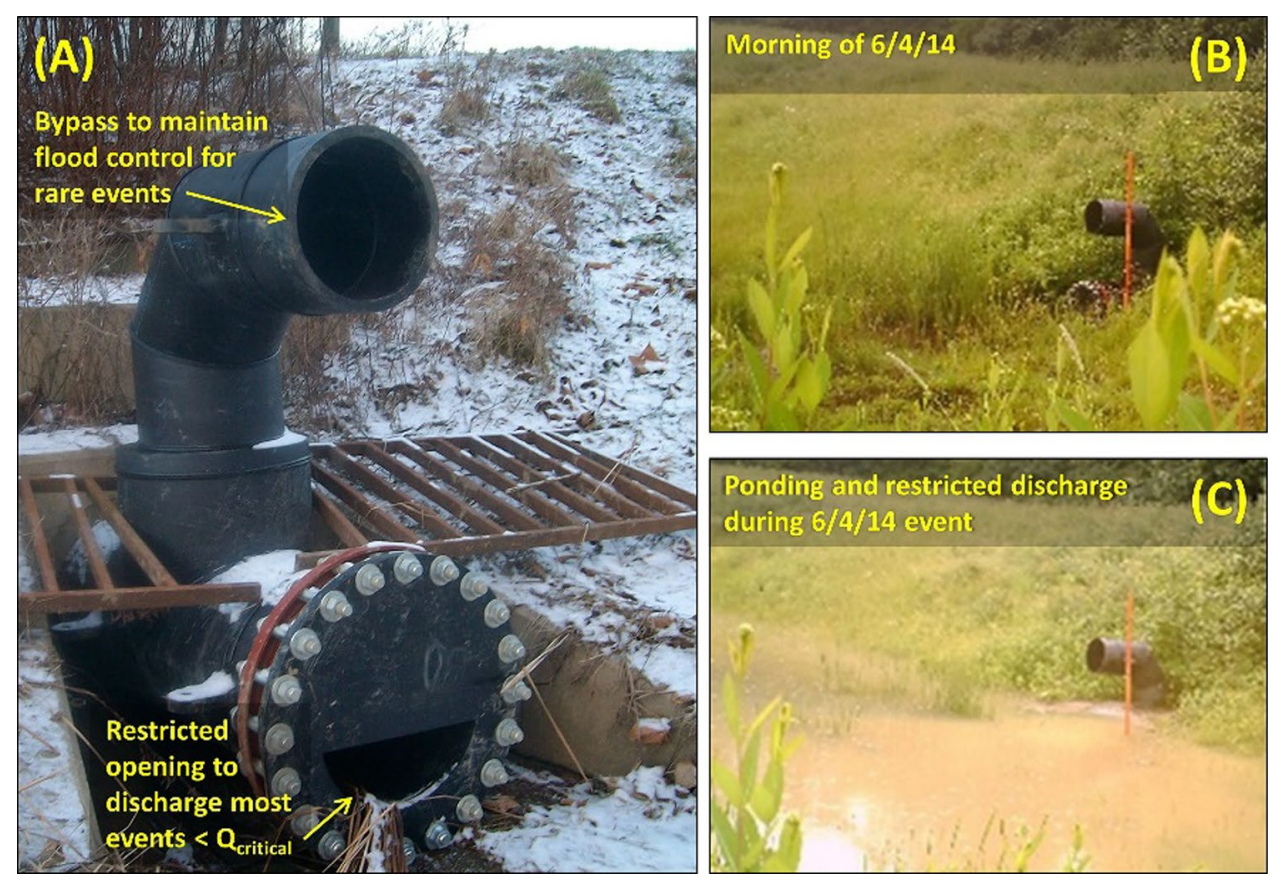


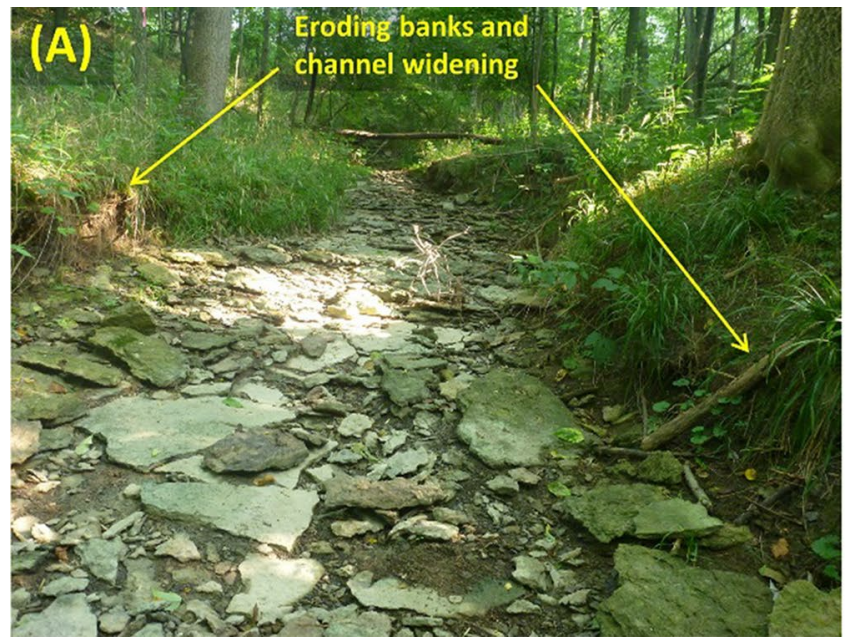

Fig. 9 The immediate receiving stream downstream of the Toyota detention basin ("Spur") was on a degradational trajectory prior to the stormwater retrofit installation, with bank erosion, channel widening, limited habitat complexity, little wood, and nominal benches evident in the $8 / 26 / 13$ photo (A). Following the SCM retrofit on $12 / 21 / 13$,

away and bank stability decreased (Fig. 10). Fine sediment from bank erosion contributed to increased embeddedness and habitat became more homogeneous as the channel trends toward an over-widened, plane bed channel. The corresponding RBP changed from 151 in 2013 to 137 in 2019 (Supplementary Materials), falling from average to poor habitat quality. The time series degradation captured at this site is consistent with other regional streams draining watersheds with more than $\sim 5 \%$ TIA that tend to systematically undergo streambed instability, headcutting, bank erosion, and channel enlargement (Hawley et al. 2013, 2020).

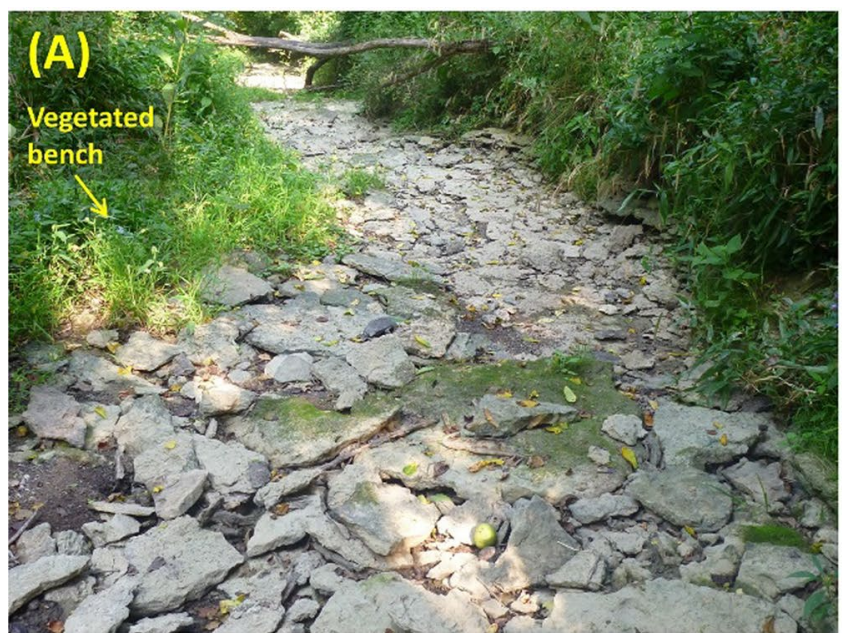

Fig. 10 The upstream control stream ("US site"), upstream of the confluence draining the retrofit detention basin, experienced a degradational trajectory in the period following the retrofit installation.

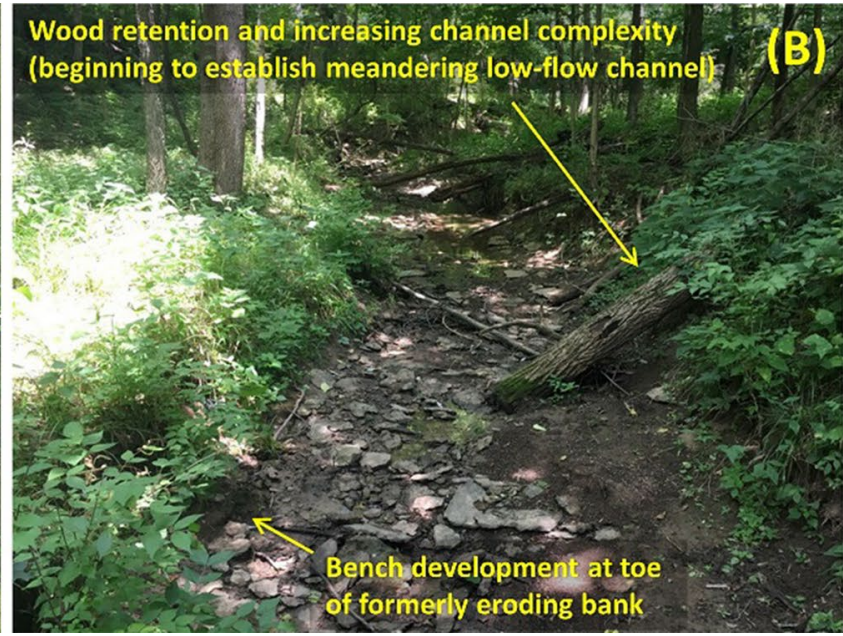

monitoring has documented a recovery trajectory with the development of vegetated benches, increased wood retention, and the beginnings of a meandering low-flow channel evident in the 7/8/19 photo (B). Both photos are looking upstream

Finally, the DS site, which drains both the Spur and the US sites, also experienced measurable improvements in bank stability and habitat quality. Cross section surveys between 2014 and 2017 documented substantial bench building at the toe of the right bank (Hawley et al. 2020), which is visually apparent in photos (Fig. 11). Similar to the Spur site, the RBP score at the DS site increased from 109 in 2013 to 146 in 2019 (Supplementary Materials), coinciding with a habitat quality improvement from poor to average. As a perennial stream with a length of $\sim 1,200$ feet $(\sim 365 \mathrm{~m})$, this would generate 450 AMUs if credited as enhancement $(1,200 \mathrm{ft} \times 0.5 \times(2.25-1.5))$ and 900

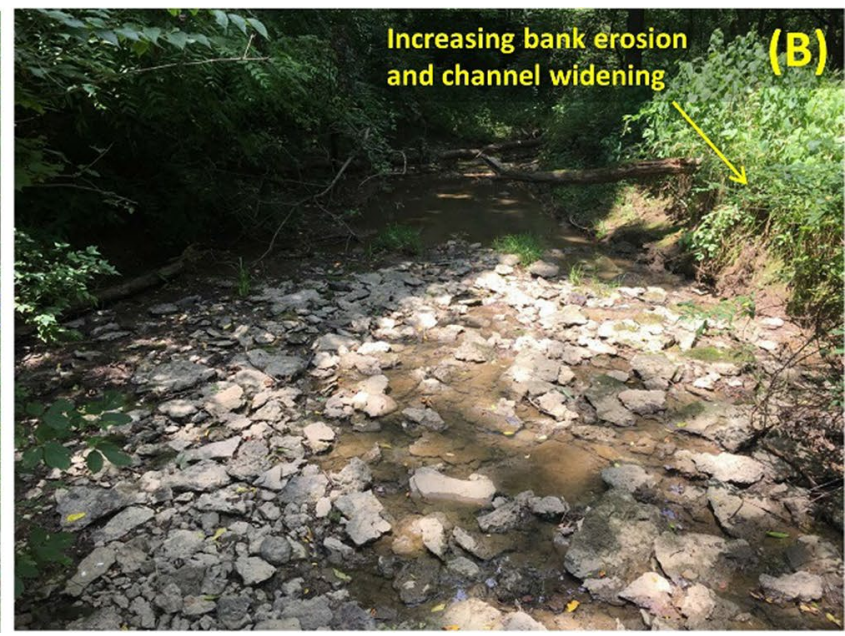

Vegetated benches that were evident in the $8 / 26 / 13$ photo (A) have since been scoured away, with bank erosion and channel widening evident in the 7/8/19 photo (B). Both photos are looking downstream 


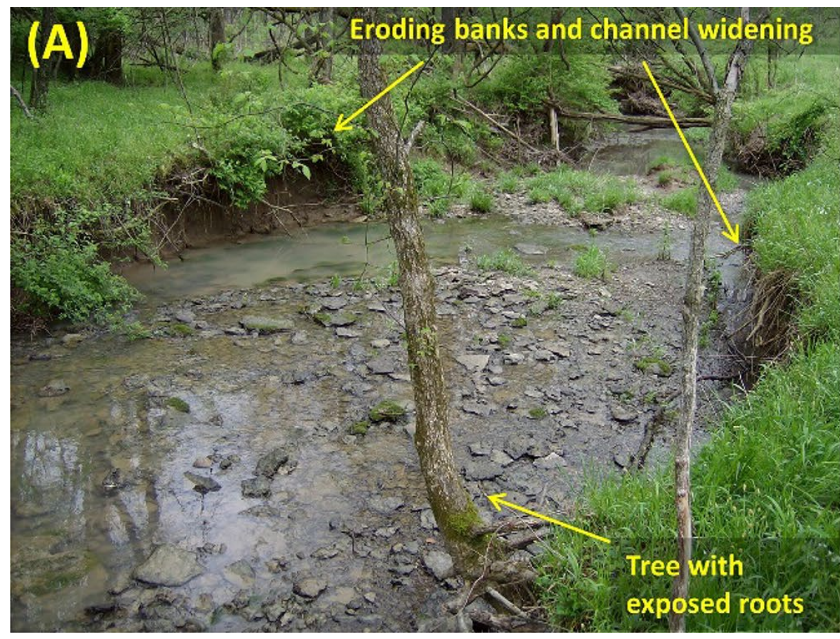

Fig. 11 The reach downstream ("DS site") of the confluence with the Spur and US control site also experienced a recovery trajectory that followed the installation of the detention basin retrofit. The photo on 4/29/13 (A) documents bank erosion, channel widening and habitat

AMUs if credited as rehabilitation $(1,200 \mathrm{ft} \times 1.0 \times(2.25$ $-1.5)$ ).

As described in greater detail by Hawley et al. (2017), the weight of this evidence suggests that the geomorphic recovery captured at the Spur and DS sites is attributable to the hydrologic restoration induced by the basin retrofit. Potentially competing hypotheses such as milder weather (which was not the case-see Hawley et al. (2017)) would not explain the inconsistency in the US control site where habitat became worse, relative to the experimental sites (Spur and DS) where habitat demonstrably improved.

By reducing the frequency, magnitude, and durations of discharges that exceed $\mathrm{Q}_{\text {critical }}$, such tailored stormwater interventions can mitigate excess streambed erosion thereby creating a shift from channel degradation and enlargement (CEM Stage 3, Fig. 3) to aggradation (CEM Stage 4) and the ultimate return of a meandering low-flow channel with vegetated benches and stable banks (CEM Stage 5). These habitat responses captured by the EPA/ ORD pilot project are summarized more generally in Table 3.

Furthermore, the ecological gains of the hydrologic-based approach could be supplemented by in-stream mitigation efforts to create even greater lifts in aquatic habitat. For example, even "low-tech" restoration approaches that rely on hand work, as opposed to heavy equipment and grading operations, (e.g. Wheaton et al. 2019; Hawley 2018) can facilitate restoration of geomorphic processes and rehabilitation. For example, on one recent Kentucky mitigation project (USACE ID: LRL2014-500-pgj), abundant installations of hand-placed log steps, toe wood, and ramped logs were used to restore habitat quality from poor to excellent (Fig. 12) on four reaches. The

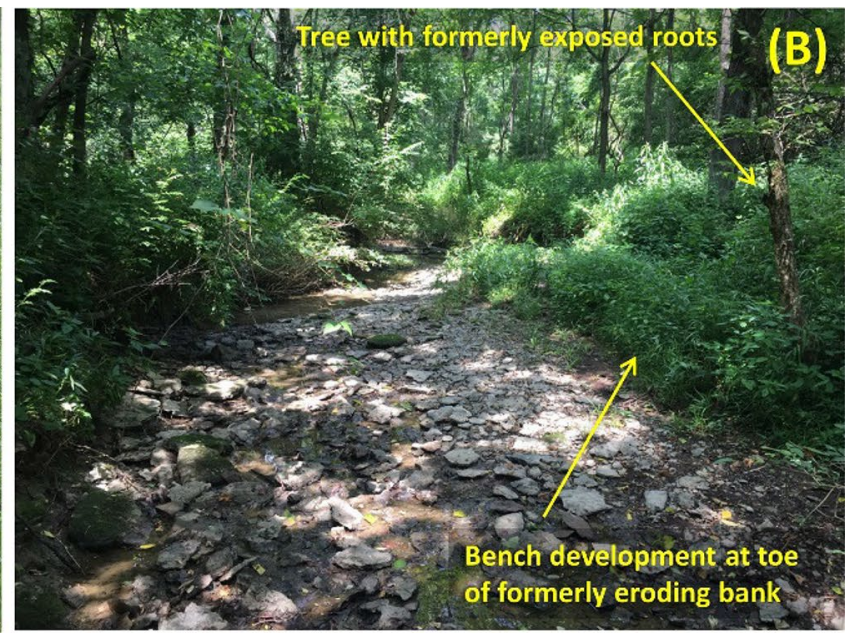

homogenization; however, the photo on 7/8/19 (B) documents bench development at the toe of a formerly eroding bank. Both photos are looking downstream (photo (B) adapted from Hawley et al. (2020))

approach substantially improves habitat complexity, expands stable benthic habitat, and enhances bank strength while preserving existing riparian trees and the associated canopy shade, leaf litter inputs, groundwater chemistry, (Wood et al. In revision) and root steps (Hawley and MacMannis 2019). The in-stream wood can also provide a carbon source for nutrient cycling and other water quality benefits (Lazar et al. 2014), whereas stable, ramped wood can play an important role in emergence of sensitive benthic macroinvertebrate taxa such as plecoptera and trichoptera (Cheney et al. 2019).

In some reaches, low-tech approaches such as handplaced logs and live stakes (Fig. 12) could potentially provide enough supplemental improvements to habitat quality to attain an even higher quality class than could be achieved through flow restoration alone. Whereas the EPA/ORD case study above increased habitat quality from poor to average, complementary log structures could conceivably improve the habitat quality to excellent similar to the Kentucky mitigation example in Fig. 12. General ranges of potential RBP improvements associated with log structures and live stakes, in addition to flow restoration RBP improvements, have been added to Table 3.

\section{Categorical lifts in flow class}

The most direct way to create stream restoration credits via hydrologic restoration is by facilitating improvements in flow class. The EPA/ORD pilot study mentioned above documented extended baseflows (Hawley et al. 2017) and the subsequent establishment of fish in several summer pools (Hawley 2018). Despite such tangible improvements, 
Table 3 Potential habitat benefits ${ }^{\mathrm{a}}$ of hydrologic restoration (with and without complementary hand-placed log structures and live stakes) by RBP category

\begin{tabular}{|c|c|c|c|}
\hline High Gradient Stream RBP Category & Potential Habitat Benefits that could & Potential Habitat Benefits tl & ould Coincide with Flow Restoration \\
\hline & & Flow Restoration & $\begin{array}{l}\text { Coupled with Log Structures \& Live } \\
\text { Stakes }\end{array}$ \\
\hline $\begin{array}{l}\text { 1. Epifaunal Substrate/ } \\
\text { Available Cover }\end{array}$ & $\begin{array}{l}\text { Expanded availability of stable benthic } \\
\text { substrate. For example, the Toyota ret- } \\
\text { rofit changed the } \mathrm{d}_{50} \text { from being mobi- } \\
\text { lized every } \sim 3 \text { months to every } \sim 2 \text { years } \\
\text { (Hawley et al. } 2017 \text { ) and increased } \\
\text { wood retention }\end{array}$ & $\sim 5-15$ points & $\sim 5-15$ additional points \\
\hline 2. Embeddedness & $\begin{array}{l}\text { Reduction of Qc events, downcutting, } \\
\text { and bank erosion and a more stable } \\
\text { (less flashy) flow regime results in the } \\
\text { gradual reduction of fine sediment avail- } \\
\text { able to embed gravels/cobbles }\end{array}$ & $\sim 2-10$ points & $\sim 5-15$ additional points \\
\hline 3. Velocity/Depth Regime & $\begin{array}{l}\text { Improvements could occur due to a } \\
\text { gradual shift from CEM Stages } 3 / 4 \\
\text { (over-widened, shallow) to CEM Stage } \\
5 \text { (narrower with a more complex cross } \\
\text { section, increased stability and greater } \\
\text { chance to create more velocity/depth } \\
\text { variability). }\end{array}$ & $\sim 0-5$ points & $\sim 0-15$ additional points \\
\hline 4. Sediment Deposition & $\begin{array}{l}\text { More time between Qc events increases } \\
\text { chances for pre-project deposition (e.g. } \\
\text { unstable bars) to be colonized by veg- } \\
\text { etation and become stable benches (e.g. } \\
\text { see Toyota DS monitoring site, Fig. 11) }\end{array}$ & $\sim 2-10$ points & $\sim 5-15$ additional points \\
\hline 5. Channel Flow Status & $\begin{array}{l}\text { More prolonged baseflows and a shift } \\
\text { from CEM Stages } 3 / 4 \text { to CEM Stage } 5 \\
\text { results in a greater portion of the active } \\
\text { channel being submerged }\end{array}$ & $\sim 2-10$ points & $\sim 0-10$ additional points \\
\hline 6. Channel Alteration & $\begin{array}{l}\text { Improvements could occur due to a } \\
\text { gradual shift from CEM Stages } 3 / 4 \\
\text { to Stage } 5 \text { and the development of a } \\
\text { meandering low-flow channel (e.g. see } \\
\text { Toyota Spur Site, Fig. 9). }{ }^{\text {b }}\end{array}$ & $\sim 0-5$ points & $\sim 0-5$ additional points \\
\hline 7. Frequency of Riffles (or Bends) & Same as above & $\sim 0-5$ points & $\sim 0-15$ additional points \\
\hline 8. Bank Stability (LB/RB) & $\begin{array}{l}\text { Deposition at toe of bank can be colo- } \\
\text { nized by vegetation (e.g. see Toyota } \\
\text { D/S, Fig. 11). Bank stability could } \\
\text { especially improve with supplemental } \\
\text { habitat enhancement (i.e. log structures) }\end{array}$ & $\sim 1-7$ points for each bank & $\sim 1-7$ additional points for each bank \\
\hline 9. Vegetative Protection (LB/RB) & Same as above & $\sim 1-7$ points for each bank & $\sim 1-7$ additional points for each bank \\
\hline $\begin{array}{l}\text { 10. Riparian Vegetative Zone Width (LB/ } \\
\text { RB) }\end{array}$ & $\begin{array}{l}\text { Could improve due to the nature of } \\
\text { mitigation projects (conservation ease- } \\
\text { ments, reforestation), but not directly as } \\
\text { a function of flow restoration }\end{array}$ & $0^{\mathrm{c}}$ points & $0-10^{\mathrm{c}}$ additional points \\
\hline
\end{tabular}

${ }^{a}$ Recall that stream mitigation credits in the conventional USACE crediting protocol used in this study are directly tied to habitat quality, such that an increase in habitat quality (Table 1) results in an increase in stream credits via Eq. 2

${ }^{\mathrm{b}}$ Quantitative changes in RBP may be less likely to improve than other RBP categories over typical monitoring time scales of mitigation projects ${ }^{\mathrm{c}}$ Could potentially improve via conservation easements, reforestation and other inherent components of mitigation projects. Flow regime and water table shifts could also induce changes to the riparian plant community

the pilot project may not have been sufficient to completely shift the jurisdictional flow class from intermittent to perennial (i.e. it may have shifted the stream from a "low" intermittent to a "high" intermittent, which would not correspond to higher flow class credits). However, two additional flow restoration projects from the region have been associated with changes in flow class.
The first example is at the Single Point Urban Interchange (SPUI) at North Bend Road and Burlington Pike in Boone County, Kentucky, where an ephemeral roadway ditch was converted into an intermittent stream-wetland complex (Fig. 13, see Supplemental Materials for locations maps). The highly impervious drainage area $(\sim 32 \%$ TIA) contains approximately 1.2 hectares of roadway and 
Fig. 12 Pre-restoration (A), $\log$ installation (B), and postrestoration after one growing season $(\mathbf{C})$ photos from a recently completed mitigation project in KY (USACE ID: LRL-2014-500-pgj) where abundant hand-placed logs and live stakes were used on four project reaches to improve habitat quality from poor to excellent. All photos are looking upstream on project reach C16b
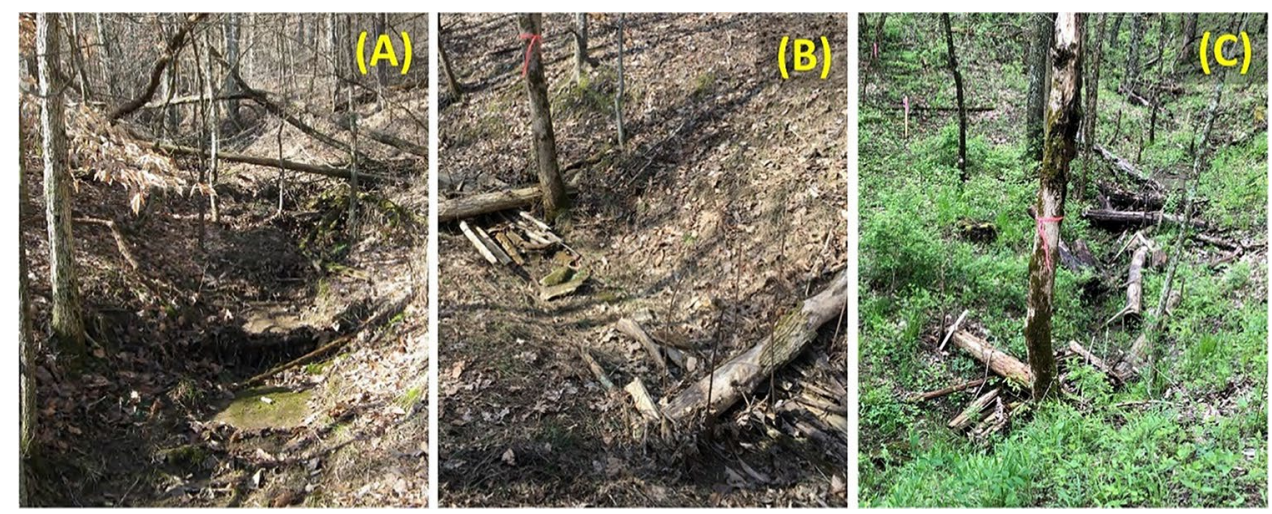

associated right-of-way. In approximately a dozen site visits since construction, the stream-wetland complex has had flow discharging to the downstream ditch on all but one occasion. Additionally, the channel and surrounding area now support wetland vegetation indicative of wetland hydrology.

Unfortunately, the mowed ditch downstream of the project is not a jurisdictional stream, and as such, no credits would be generated from this project (despite the clear improvement in flow class). However, the example shows how more sustainable management of stormwater flows could improve the flow class in jurisdictional channels. For example, if the $\sim 450-\mathrm{ft}(\sim 135 \mathrm{~m})$ receiving channel was jurisdictional, a flow class change from ephemeral to intermittent would be associated with a range of additional credits depending on the Initial Quality and Mitigation Ratio.

On the low end, converting a poor-quality ephemeral stream (Quality value of 0.5 ) to a poor-quality intermittent stream (Quality value of 1.0) would generate 112.5 AMUs if credited as enhancement $(450 \mathrm{ft} \times 0.5 \times(1.0-0.5))$ and 225 AMUs if credited as rehabilitation $(450 \mathrm{ft} \times 1.0 \times(1.0$ $-0.5)$ ). An average-quality ephemeral stream (Quality value of 0.75 ) that was transformed into an average-quality intermittent stream (Quality value of 1.5 ) would create 168.75 AMUs if credited as enhancement $(450 \mathrm{ft} \times 0.5 \times(1.5$ $-0.75)$ ) and 337.5 AMUs if credited as rehabilitation (450 $\mathrm{ft} \times 1.0 \times(1.5-0.75))$. On the high end, an excellent-quality ephemeral stream (Quality value of 1.0) that transitioned to an excellent-quality intermittent stream (Quality value of 2.0) would produce 225 AMUs if credited as enhancement $(450 \mathrm{ft} \times 0.5 \times(2.0-1.0))$ and 450 AMUs if credited as rehabilitation $(450 \mathrm{ft} \times 1.0 \times(2.0-1.0))$.

These hypothetical stream mitigation credits would increase even further if the non-jurisdictional receiving ditch could have been re-established as a jurisdictional stream via complementary habitat restoration, which would have coincided with improvements to habitat quality in addition to flow class (see next section). In the case of the SPUI project, if the $\sim 450$ feet $(\sim 135 \mathrm{~m})$ of poor-quality ephemeral roadside ditch could have been re-established as an excellentquality intermittent stream the project would have generated 900 AMUs if credited as re-establishment $(450 \mathrm{ft} \times 1.0 \mathrm{x}$ $(2.0-0.0))$. The reach would have had no associated debits due to the fact that the former ditch was not jurisdictional. Furthermore, by creating a jurisdictional connection to the stream/wetland complex, the $\sim 200$-ft long intermittent
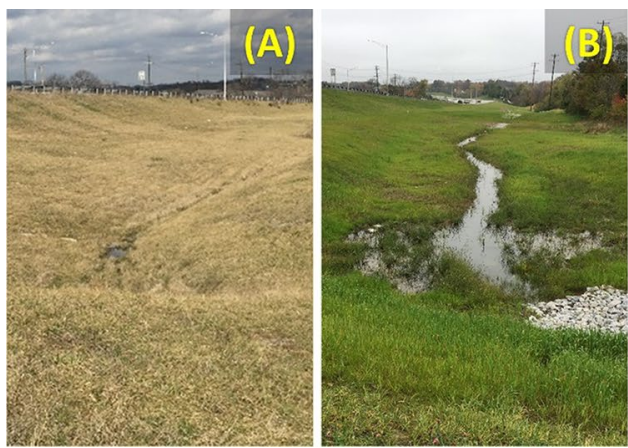

Fig. 13 (A) Looking downstream at the SPUI project site prior to restoration documenting a mostly dry, grassed swale on a winter day $(2 / 23 / 17)$. (B) Looking downstream at the restored stream-wetland complex on an autumn day (11/3/17) with wet pools and riffles. (C)

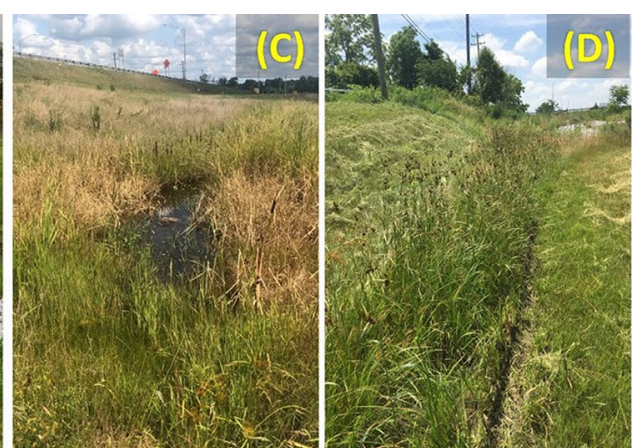

Looking downstream at the restored stream-wetland complex with ponding and wetland vegetation on a summer day (7/27/18). (D) Looking upstream at the receiving ditch with wetland vegetation that is too wet to mow despite summer conditions $(7 / 8 / 19)$ 
stream with excellent habitat that was re-established within the wetland could have generated an additional 400 AMUs $(200 \mathrm{ft} \times 1.0 \times(2.0-0.0))$ and had no debits due to the nonjurisdictional ditch that it replaced.

\section{Categorical lifts in flow class and habitat quality}

A final example involves improvements in both flow class and habitat quality. It was facilitated by construction of a two-cell stormwater wetland as a part of a stream mitigation project in Boone County, Kentucky (USACE ID: LRL2009-329-pgj, see Supplemental Material for location maps). The stormwater wetland intercepts formerly undetained impervious surfaces that drain to the Boone Woods mitigation project. The two cells are connected via pipe, which allows the upper wetland to slowly release flows to the lower wetland over a 48-h period, which in turn gradually discharges to the receiving stream network. Onsite monitoring in 2014 revealed significant reductions in peak discharges, reducing one rain event (91 mm over $24 \mathrm{~h}$ ) from a peak inflow of $1.57 \mathrm{~m}^{3} / \mathrm{s}$ to a peak outflow of only 0.01 $\mathrm{m}^{3} / \mathrm{s}$ (Brown and Hopfensperger 2014). In addition to mitigating erosive flows, the stormwater wetland discharges perennial baseflow to the stream network.

The substantial improvements to the flow regime coincided with re-establishment of a jurisdictional stream in place of a non-jurisdictional ephemeral swale. According to the project's Year 5 Monitoring Report (2016), the reestablished $144 \mathrm{ft}$ (44 m) of average-quality perennial stream was associated with 324 AMUs $(144 \mathrm{ft} \times 1.0 \times(2.25-0.0))$ and no debits because the pre-project swale was not jurisdictional. Furthermore, the flow class benefits of the stormwater wetland have persisted since the completion of the Mitigation Project's monitoring — the basin outfall was independently observed with trickle flow during summer low-flow periods on $7 / 8 / 19$.

Table 4 Summary of flow class improvement examples and associated mitigation credits (with and without supplemental improvements in habitat quality)

\begin{tabular}{|c|c|c|c|}
\hline Project & $\begin{array}{l}\text { Project Observations related to } \\
\text { Flow Class }\end{array}$ & $\begin{array}{l}\text { Potential Credits Generated Exclu- } \\
\text { sively by Flow Class Improvement } \\
\text { (excluding any credits from habitat } \\
\text { improvement) }\end{array}$ & $\begin{array}{l}\text { Potential Credits Generated with } \\
\text { Observed/Potential Habitat improve- } \\
\text { ments }\end{array}$ \\
\hline EPA/ORD Pilot (i.e. Toyota) & $\begin{array}{l}\text { Changed immediate receiving } \\
\text { stream reach ("Spur", } 800 \mathrm{ft} \text {, } \\
244 \mathrm{~m}) \text { from low intermittent } \\
\text { to high intermittent. DS reach } \\
(1,200 \mathrm{ft}, 366 \mathrm{~m}) \text { remained } \\
\text { perennial }\end{array}$ & $\begin{array}{l}0 \text { AMUs } \\
\text { (No change in flow class) }\end{array}$ & 650 AMUs $^{\mathrm{a}}$ \\
\hline SPUI Stream/wetland Complex & $\begin{array}{l}\text { Changed both the on-site ditch } \\
(200 \mathrm{ft}, 61 \mathrm{~m}) \text { and the down- } \\
\text { stream ditch }(450 \mathrm{ft}, 137 \mathrm{~m}) \text { from } \\
\text { ephemeral to intermittent flow } \\
\text { class }\end{array}$ & $\begin{array}{l}\text { 162.5 } \text { AMUs }^{\mathrm{b}} \\
\text { (If the ditches would have been } \\
\text { jurisdictional streams) }\end{array}$ & $\begin{array}{l}1,300 \mathrm{AMUs}^{\mathrm{c}} \\
\text { (If the ditches were re-established as } \\
\quad \text { jurisdictional streams) }\end{array}$ \\
\hline Boone Woods & $\begin{array}{l}\text { Changed reach }(144 \mathrm{ft}, 44 \mathrm{~m}) \text { from } \\
\text { ephemeral to perennial flow class }\end{array}$ & $\begin{array}{l}72 \text { AMUs }^{\mathrm{d}} \\
\text { (if channels were jurisdictional } \\
\text { without the concurrent habitat } \\
\text { work) }\end{array}$ & $\begin{array}{l}324 \mathrm{AMUs}^{\mathrm{e}} \\
\text { (actual mitigation project credits) }\end{array}$ \\
\hline
\end{tabular}

a Credits associated with improving both the Spur and the DS reaches from poor quality to average quality using an "Enhancement" Mitigation Ratio of 0.5 , i.e. $(800 \mathrm{ft} \times 0.5 \times(1.5-1.0))+(1,200 \mathrm{ft} \times 0.5 \times(2.25-1.5))$. Credits could increase to 1,300 AMUs if credited as "Rehabilitation" and up to 2,600 AMUs if rehabilitated with complementary log structures and live stakes (i.e. an associated improvement from poor quality to excellent quality).

${ }^{\mathrm{b}}$ Hypothetical credits if the pre-project and post-project ditches were jurisdictional streams. Credits assume a pre-project and post-project habitat quality of poor, a change in flow class from ephemeral to intermittent, and an "Enhancement" Mitigation Ratio of 0.5. Credits include both the receiving ditch $(450 \mathrm{ft})$ and the ditch within the SPUI wetland $(200 \mathrm{ft})$, i.e. $(450 \mathrm{ft} \times 0.5 \times(1.0-0.5))+(200 \mathrm{ft} \times 0.5 \times(1.0-0.5))$.

${ }^{c}$ Potential credits with the SPUI project if the non-jurisdictional ditches could have been re-established as excellent-quality intermittent streams. This would require complementary log structures, live stakes, and/or re-meandering of the downstream reach. This calculation uses a "Re-establishment" Mitigation Ratio of 1.0 with no associated debits (pre-project ditches were non-jurisdictional), i.e. $(450 \mathrm{ft} \times 1.0 \mathrm{x}(2.0-$ $0.0)+(200 \mathrm{ft} \times 1.0 \times(2.0-0.0))$.

d Assumes that the pre-project swale and post-project swale without any concurrent re-establishment work would have been jurisdictional. Hypothetical credits are based on the difference between poor perennial (Quality Value of 1.5) and poor ephemeral (Quality Value of 0.5) and an "Enhancement" Mitigation Ratio of 0.5, i.e. $(144 \mathrm{ft} \times 0.5 \times(1.5-0.5))$.

e Credits that were actually associated with the mitigation project, which combined a flow class lift (ephemeral to perennial) and a habitat lift from non-jurisdictional to average using a "Re-establishment" Mitigation Ratio of 1.0 with no associated debits (pre-project swale was nonjurisdictional), i.e. $(144 \mathrm{ft} \times 1.0 \times(2.25-0.0)$ 
In summary, the three examples of potential flow class improvement showcased herein document a range of potential mitigation credits (Table 4). In cases where the receiving channel was not jurisdictional, or the flow improved but did not switch flow classes, no restoration credits would be directly attributable to flow restoration. However, in all cases, the potential stream credits substantially expand when considering the additional AMUs associated with both indirect and direct habitat improvements.

\section{Conclusions}

Stream mitigation crediting protocols in the US are a legal mechanism to compensate USACE-approved mitigation projects for stream restoration interventions using fees generated by stream impacts. Crediting protocols have traditionally been applied to conventional stream restoration projects that physically restore habitat via in-stream construction. However, USACE stream mitigation protocols could also be applied to hydrologic-based mitigation activities that create demonstrable improvements in stream integrity. For example, flow restoration can generate stream mitigation credits via the Central Kentucky Assessment Protocol by:

1) lifting the flow class of a restoration reach(es), e.g. from ephemeral to intermittent,

2) restoring process-based habitat recovery, e.g. bench development, bank re-stabilization, and an overall shift from channel degradation (CEM Stage 3) to geomorphic equilibrium (CEM Stage 5, Fig. 3), and/or

3) supplemental in-stream habitat restoration efforts such as channel re-establishment, installation of hand-placed wood structures, etc.

Similar to conventional habitat mitigation projects, judgment is required to determine a mitigation ratio that is commensurate with the level of intervention. For example, in the case of a simple retrofit to a single existing stormwater detention basin, enhancement (Mitigation Ratio of 0.5) may be most appropriate. In cases where existing stormwater facilities are retrofit more substantially (e.g. expanded storage through grading, conversion to a wetland or filtration basin, etc.), new stormwater controls are installed (e.g. construction of new stream-wetland complexes), and/or stormwater interventions are supplemented by in-stream habitat restoration (e.g. hand-placed log structures and live stakes), rehabilitation (Mitigation Ratio of 1.0) may be more appropriate. Finally, projects that re-establish a jurisdictional stream in place of a non-jurisdictional swale should likely be credited as re-establishment (Mitigation Ratio of 1.0) and would not be associated with any debits due to the lack of a jurisdictional channel prior to mitigation.
Any credited stream lengths would inherently require conventional protection instruments (e.g. conservation easements or equivalent), and reaches with limited buffers would coincide with reduced mitigation ratios (Table 2). Site protections and/or maintenance agreements would also need to be tailored to the associated stormwater interventions to ensure that the hydrologic benefits persist beyond the monitoring period of the project.

Monitoring plans will need to be designed to capture the flow class changes and/or habitat improvements of representative project reaches and how far downstream they persist. Although there is unlikely to be a clear threshold, it is reasonable to assume that hydrologic interventions need to intercept a meaningful portion of a watershed's impervious area and/or drainage area to be likely to show measurable improvements in receiving stream habitat and/or flow class (i.e. recall that the Toyota retrofit only controlled $\sim 13 \%$ of the drainage area to the "DS site" but intercepted $\sim 47 \%$ of its impervious area). The scale of stormwater intervention, complementary in-stream habitat mitigation, the hydroclimatic setting, and weather during the monitoring period, among other factors, could all affect the rate of measurable geomorphic recovery in the receiving streams (i.e. recall that the Toyota project documented quantifiable habitat improvements over a five-year recovery period following the stormwater retrofit).

Similar to conventional in-stream habitat mitigation projects, hydrologic-based stream mitigation will likely require customized Mitigation Plans tailored to the ecological potential of the urban setting (e.g. Paul et al. 2009). Although each project will be unique (e.g. how to proportion credits in the case of multiple project stakeholders?), the examples herein suggest that stormwater mitigation projects could use mitigation protocols, success metrics, and monitoring timeframes that are comparable to conventional mitigation projects. Like any new approach, adaptive management (i.e. corrective actions to address mitigation deficiencies identified during monitoring) could be used to accommodate particular needs of stormwater mitigation strategies. Furthermore, project partners could be encouraged to participate in conventional knowledge transfer venues to help share lessons learned and continue to advance the state of the industry toward more sustainable stream restoration outcomes.

Supplementary Information The online version contains supplementary material available at https://doi.org/10.1007/s11252-021-01139-x.

Acknowledgements The author would like to thank two anonymous Reviewers and Guest Editor Sujay Kaushal for their highly constructive reviews that substantially strengthened the paper. Matt Wooten and Jim Gibson of SD1 and Nora Korth of Sustainable Streams provided helpful reviews of an earlier version of this manuscript. Nora Korth and Shelby Acosta of Sustainable Streams helped with the development of the credit scenarios in this case study and the maps in the Supplemental Material. Much of the case study draws on previous papers and 
analyses - I am so very grateful to collaborators, funding sources, and field staff who supported those efforts.

Author's contributions This article was written entirely by Robert J. Hawley. See acknowledgements for staff who helped develop the credit scenarios and individuals who provided reviews.

Funding This manuscript was funded in part by SD1, the manager of Northern Kentucky's wastewater and stormwater. SD1 has legal and financial interests in managing stormwater in ways that reduce stream erosion, and improve water quality, habitat, and biological function. Consistent with SD1's Strategic Business Plan, this includes finding ways to help pay for management interventions that could contribute to achieving these goals, such as projects that could improve stream habitat and generate stream mitigation credits.

Data availability provided in "supplemental material."

\section{Declarations}

Competing interests See funding statement.

Open Access This article is licensed under a Creative Commons Attribution 4.0 International License, which permits use, sharing, adaptation, distribution and reproduction in any medium or format, as long as you give appropriate credit to the original author(s) and the source, provide a link to the Creative Commons licence, and indicate if changes were made. The images or other third party material in this article are included in the article's Creative Commons licence, unless indicated otherwise in a credit line to the material. If material is not included in the article's Creative Commons licence and your intended use is not permitted by statutory regulation or exceeds the permitted use, you will need to obtain permission directly from the copyright holder. To view a copy of this licence, visit http://creativecommons.org/licenses/by/4.0/.

\section{References}

Barbour MT, Gerritsen J, Snyder BD, Stribling JB (1999) "Rapid bioassessment protocols for use in streams and wadeable rivers: Periphyton, benthic macroinvertebrates and fish." In. Washington, DC: U. S. Environmental Protection Agency, Office of Water.

Bhaskar AS, Beesley L, Burns MJ, Fletcher TD, Hamel P, Oldham CE, Roy AH (2016) 'Will it rise or will it fall? Managing the Complex Effects of Urbanization on Base Flow'. Freshwater Science 35:293-310

Bixler P, Belaire A, Faust K, Scoggins, Gonzales A (In review) 'Exploring the connection between transdisciplinary co-production and urban stream sustainability solutions: A case study at an urban stream management symposium'. Urban Ecosyst

Blauch GA, Jefferson AJ (2019) 'If a tree falls in an urban stream, does it stick around? Mobility, Characteristics, and Geomorphic Influence of Large Wood in Urban Streams in Northeastern Ohio, USA', Geomorphology 337:1-14

Bledsoe BP (2002) Stream erosion potential associated with stormwater management strategies. J Water Resour Plan Manag 128:451-455

Booth DB (1990) Stream-channel incision following drainage-basin urbanization. Water Resour Bull 26:407-417

Booth DB (2005) Challenges and prospects for restoring urban streams: A perspective from the Pacific Northwest of North America. J N Am Benthol Soc 24:724-737
Booth DB, Fischenich CJ (2015) A channel evolution model to guide sustainable urban stream restoration. Area 47:408-421

Brown J, Hopfensperger K (2014) "Monitoring the efficiency of a constructed wetland." In Annual Meeting of the Kentucky Academy of Science, edited by K.C. Russell, 66. Lexington Convention Center, Lexington, KY: Kentucky Academy of Science

Cheney KN, Roy AH, Smith RF, DeWalt RE (2019) 'Effects of stream temperature and substrate type on emergence patterns of plecoptera and trichoptera from northeastern United States headwater streams'. Environ Entomol, nvz106

Cluer B, Thorne C (2014) A stream evolution model integrating habitat and ecosystem benifits. River Res Appl 30:135-154

County K (2013) "Development of a Stormwater Retrofit Plan for Water Resources Inventory Area 9: SUSTAIN Model Pilot Study." In, 89. Water and Land Resources Division. Seattle, Washington

EPA (2009) "National Water Quality Inventory: Report to Congress, 2004 Reporting Cycle." In. Washington, D.C.: United States Environmental Protection Agency

Finkenbine JK, Atwater JW, Mavinic DS (2000) Stream health after urbanization. J Am Water Resour Assoc 36:1149-1160

Hammer TR (1972) Stream channel enlargement due to urbanization. Water Resour Res 8:139-167

Harman WA, Starr R, Carter M, Tweedy K, Clemmons M, Suggs K, Miller C (2012) "A function-based framework for stream assessment and restoration projects." In, 344. Washington, D.C.: US Environmental Protection Agency, Office of Wetlands, Oceans, and Watersheds

Hawley RJ (2018) Making stream restoration more sustainable: A geomorphically, ecologically, and socioeconomically principled approach to bridge the practice with the science. Bioscience 68:517-528

Hawley RJ, Bledsoe BP (2011) 'How do flow peaks and durations change in suburbanizing semi-arid watersheds? A Southern California Case Study'. J Hydrol 405:69-82

Hawley RJ, Bledsoe BP (2013) Channel enlargement in semi-arid suburbanizing watersheds: a southern California case study. J Hydrol 496:17-30

Hawley RJ, Bledsoe BP, Stein ED, Haines BE (2012) Channel evolution model of semiarid stream response to urban-induced hydromodification. J Am Water Resour Assoc 48:722-744

Hawley RJ, Goodrich JA, Korth NL, Rust CJ, Fet EV, Frye C, MacMannis KR, Wooten MS, Sinha R (2017) Detention outlet retrofit device improves the functionality of existing detention basins by reducing erosive flows in receiving channels. J Am Water Resour Assoc 53:1032-1047

Hawley RJ, Goodrich JA, MacMannis KR (2019) Detain H2O Detention Pond Retrofit Device. In, edited by United States Patent Office, 9. U.S. Serial Number 61/958,027: The United States of America as Represented by the Administrator of the U.S. Environmental Protection Agency, Washington, DC (US). Sustainable Streams, LLC, Louisville, KY (US)

Hawley RJ, MacMannis KR (2019) Tree roots as a dominant agent of streambed habitat, profile pattern, and grade control. Geomorphology 343:81-91

Hawley RJ, MacMannis KR, Wooten MS (2013) Bed coarsening, riffle shortening, and channel enlargement in urbanizing watersheds, northern Kentucky, U.S.A. Geomorphology 201:111-126

Hawley RJ, MacMannis KR, Wooten MS, Fet EV, Korth NL (2020) Suburban stream erosion rates in northern Kentucky exceed reference channels by an order of magnitude and follow predictable trajectories of channel evolution. Geomorphology 1;352:106998

Hawley RJ, Vietz GJ (2016) Addressing the urban stream disturbance regime. Freshwater Science 35:278-292

Hawley RJ, Wooten MS, MacMannis KR, Fet EV (2016) 'When do macroinvertebrate communities of reference streams resemble 
urban streams? The Biological Relevance of Qcritical', Freshwater Science 35:778-794

Herrington C, Horndeski K (In review) 'Is urban stream restoration really a wicked problem?', Urban Ecosyst

Holomuzki JR, Biggs BJF (2000) Taxon-specific responses to highflow disturbance in streams: implications for population persistence. J N Am Benthol Soc 19:670-679

Jefferson AJ, Bhaskar AS, Hopkins KG, Fanelli R, Avellaneda PM, McMillan SK (2017) Stormwater management network effectiveness and implications for urban watershed function: A critical review. Hydrol Process 31:4056-4080

Kaushal S, Fork M, Hawley R, Hopkins K, Rios-Touma B, Roy A (Forthcoming) 'Milestones to evaluating stream restoration successes and failures: Synthesizing the state of the science across time and space', Urban Ecosyst

KDOW (2008) Integrated Report to Congress on Water Quality in Kentucky. Volume I. 305(b) Report. In. Frankfort, KY: Kentucky Energy and Environment Cabinet, Department for Environmental Protection, Division of Water

KDOW (2011) Methods for Assessing Habitat in Wadeable Waters. In, 27. Frankfort, KY: Commonwealth of Kentucky, Energy and Environment Cabinet, Department for Environmental Protection, Division of Water

KDOW (2015) Methods for Sampling Benthic Macroinvertebrate Communities in Wadeable Waters. In. Frankfort, KY: Kentucky Department of Environmental Protection, Division of Water

Kowalski DA, Richer EE (2020) Quantifying the habitat preferences of the stonefly Pteronarcys californica in Colorado. River Res Appl 36:2043-2050

Lammers RW, Dell TA, Bledsoe BP (2019) 'Integrating stormwater management and stream restoration strategies for greater water quality benefits'. J Environ Qual

Lazar JG, Gold AJ, Addy K, Mayer PM, Forshay KJ, Groffman PM (2014) Instream large wood: Denitrification hotspots with low N2O production. J Am Water Resour Assoc 50:615-625

Meyer JL, Strayer DL, Bruce Wallace J, Eggert SL, Helfman GS, Leonard NE (2007) The contribution of headwater streams to biodiversity in river networks. J Am Water Resour Assoc 43:83-103

NRC (2009) Urban Stormwater Management in the United States. In. Washington, D.C.: National Research Council

OEPA (2010) Ohio 2010 integrated water quality monitoring and assessment report. In. Columbus, OH: State of Ohio, Environmental Protection Agency

Papangelakis E, MacVicar B, Ashmore P (2019) Bedload sediment transport regimes of semi-alluvial rivers conditioned by urbanization and stormwater management. Water Resour Res 55(12):10565-87

Paul MJ, Bressler DW, Purcell AH, Barbour MT, Rankin ET, Resh VH (2009) Assessment tools for urban catchments: defining observable biological potential. J Am Water Resour Assoc 45:320-330

Paul MJ, Meyer JL (2001) Streams in the urban landscape. Annu Rev Ecol Syst 32:333-365
Pizzuto JE, Hession WC, McBride M (2000) Comparing gravel-bed rivers in paired urban and rural catchments of southeastern Pennsylvania. Geology 28:79-82

Plafkin JL, Barbour MT, Porter KD, Gross SK, Hughes RM (1989) Rapid Bioassessment Protocols for Use in Streams and Rivers: Benthic Macroinvertbrates and Fish. In. Washington, DC: United States Environmental Protection Agency

Russell KL, Vietz GJ, Fletcher TD (2018) Urban catchment runoff increases bedload sediment yield and particle size in stream channels. Anthropocene 23:53-66

Schumm SA, Harvey MD, Watson CC (1984) Incised channels: Morphology, Dynamics, and Control. Littleton, Colorado, Water Resources Publications

Simon A, Klimetz L (2008) Relative magnitudes and sources of sediment in benchmark watersheds of the Conservation Effects Assessment Project. J Soil Water Conserv 63:504-522

Smith RF, Hawley RJ, Neale MW, Vietz GJ, Diaz-Pascacio E, Hermann J, Lovell AC, Prescott C, Rios-Touma B, Smith B, Utz RM (2016) Urban stream renovation: incorporating societal objectives to achieve ecological improvements. Freshwater Science 35:364-379

TDEC (2018) Tennessee Stream Quantification Tool Rapid Data Collection Methods. In $T N S Q T$ v 1.0, 57. Nashville, TN: Tennessee Department of Environment and Conservation (TDEC)

USACE (2009) "Notice announcing issuance of rate increase, and method for assessing credits, for the Kentucky In-Lieu Fee Program." U.S. Army Corps of Engineers, Louisville District

Vietz GJ, Hawley RJ (2019) Protecting and Managing Stream Morphology in Urban Catchments Using WSUD. in A. Sharma, D. Begbie and T. Gardner (eds.), Approaches to Water Sensitive Urban Design (Elsevier)

Vietz GJ, Sammonds MJ, Walsh CJ, Fletcher TD, Rutherfurd ID, Stewardson MJ (2014) Ecologically relevant geomorphic attributes of streams are impaired by even low levels of watershed effective imperviousness. Geomorphology 206:67-78

Walsh CJ, Fletcher TD, Ladson AR (2005a) Stream restoration in urban catchments through redesigning stormwater systems: looking to the catchment to save the stream. J N Am Benthol Soc 24:690-705

Walsh CJ, Roy AH, Feminella JW, Cottingham PD, Groffman PM, Raymond Morgan II, P. (2005b) The urban stream syndrome: current knowledge and the search for a cure. J N Am Benthol Soc 24:706-723

Wheaton JM, Bennett SN, Bouwes N, Maestas JD, Shahverdian SM (ed.) ${ }^{\wedge}$ (eds.) (2019) Low-tech process-based restoration of riverscapes: Design manual (Utah State University Restoration Consortium: Logan, UT)

Wood KL, Kaushal SS, Vidon PG, Mayer PM, Galella JG (In revision) Tree trade-offs in stream restoration: Impacts on riparian groundwater quality. Urban Ecosyst 